\title{
PENGARUH PEMERIKSAAN PAJAK TERHADAP KEPATUHAN WAJIB PAJAK BADAN DI KANTOR PELAYANAN PAJAK MEDAN PETISAH
}

\author{
SABETH SEMBIRING ${ }^{1}$ \\ RIA VERONICA SINAGA ${ }^{2}$ \\ ANGELINA GINTING ${ }^{3}$ \\ ${ }^{1,2,3}$ Fakultas Ekonomi Program Studi Akuntansi Universitas Katolik Santo Thomas, \\ sabethsembiring@gmail.com, riaveronicas@gmail.com, gintingangel65@gmail.com
}

\begin{abstract}
ABSTRAK
Tujuan dilakukan penelitian ini adalah untuk Untuk mengetahui penyebab tidak tercapainya target penerimaan pajak berdasarkan penyelesaian Surat Perintah Pemeriksaan (SP2) di KPP Pratama Lubuk Pakam dan mengetahui faktor faktor yang mendukung pelaksanaan pemeriksaan dan faktor-faktor penghambat yang dihadapi dalam pelaksanaan pemeriksaan. Data yang digunakan dalam penelitian ini adalah data penyelesaian Surat Perintah Pemeriksaan (SP2) dan data target dan realisasi penerimaan pajak dari hasil pemeriksaan berdasarkan Surat Perintah Pemeriksaan (SP2) di KPP Pratama Lubuk Pakam. Sampel yang digunakan dalam penelitian ini adalah jumlah penyelesaian Surat Perintah Pemeriksaan (SP2) tahun 2016-2018. Jenis data yangdigunakan adalah data sekunder. Metode pengumpulan data dalam penelitian ini dilakukan melalui metode wawancara dan dokumentasi. Metode analisis data menggunakan metode analisis deskriptif. Hasil penelitian dari efektivitas pelaksanaan pemeriksaan pajak dalam rangka meningkatkan penerimaan pajak di KPP Pratama Lubuk Pakam menunjukkan belum dapat mencapai target yang telah ditentukan, karena adanya faktor-faktor penghambat yang mempengaruhi pelaksanaan pemeriksaan tersebut yang bersifat internal maupun eksternal, yaitu jumlah pemeriksa yang kurang, terlalu luas wilayah KPP Pratama Lubuk Pakam, tingkat pengetahuan Wajib Pajak yang kurang tentang pajak, pembukuan wajib pajak yang kurang lengkap dan kurang sesuai dengan standart perpajakan serta wajib pajak yang pindah alamat tanpa memberitahu dulu pada KPP Pratama Lubuk Pakam.
\end{abstract}

Kata Kunci : Pelaksanaan Pemeriksaan Pajak, Penerimaan Pajak, Efektivitas

\section{PENDAHULUAN}

Pajak memiliki peran yang sangat penting dalam perekonomian di Indonesia, dan salah satu sumber penerimaan Negara yang terbesar adalah berasal dari penerimaan pajak. Pemungutan pajak di Indonesia secara kelembagaan merupakan tanggung jawab dari Direktorat Jenderal Pajak yang selaku pengelola pemungutan pajak pusat, namun secara keseluruhan pemungutan pajak di Indonesia merupakan tanggung jawab bersama seluruh masyarakat terutama Wajib Pajak. Kepatuhan Wajib Pajak dalam membayar pajak sangat menentukan tercapai atau tidaknya target penerimaan pajak di Indonesia yang menganut self assessment system. Oleh karena itu terhadap Wajib Pajak yang melakukan kecurangan dan lalai akan pemenuhan kewajibannya perlu dilakukan pemeriksaan untuk menguji kepatuhan dan menegakkan peraturan perpajakan (law enforcement) yang mempunyai kekuatan hukum memaksa sesuai dengan prosedur yang telah ditetapkan dalam UU perpajakan.

Tindakan pemeriksaan ini dilakukan sebagai sarana penegakan hukum (law enforcement) bagi Wajib Pajak (WP) atau Penanggung Pajak (PP) yang lalai dalam memenuhi kewajiban perpajakannya, untuk memperkecil jumlah tunggakan pajak yang terutang oleh Wajib Pajak, dan merupakan salah satu langkah penting dalam mengamankan dan meningkatkan penerimaan negara dari sektor pajak. Jika hal tersebut dapat dilaksanakan dengan sebaikbaiknya dan faktor-faktor penghambat dalam pelaksanaan pemeriksaan dapat diatasi maka upaya peningkatan penerimaan negara dari sektor pajak tentunya akan tercapai.

Efektivitas berasal dari kata efektif yang artinya sesuatu kemampuan untuk menghasilkan hasil yang spesifik atau mendesakkan pengaruh yang spesifik yang terukur. Dalam skala mikro, kondisi Kabupaten Deli Serdang sangat strategis dengan penduduk yang padat dan memiliki mobilitas kegiatan ekonomi yang tinggi sehingga memberi peluang untuk menggali 
potensial, karena itu sangat mungkin ada wajib pajak yang tidak membayar tepat waktu atau bahkan tidak membayar sama sekali.

Sitanggang (2014), yang melakukan penelitian mengenai Efektivitas Pelaksanaan Pemeriksaan dalam upaya meningkatkan penerimaan pajak di KPP Pratama Manado. Peneliti yang dilakukan menggunakan metode analisis deskriptif. Adapun persamaan penelitian ini terdapat pada tujuan untuk mengetahui efektivitas pelaksanaan pemeriskaan yang dilakukan KPP, sedangkan perbedaannya terletak pada objek penelitian dan tahun penelitiannya.

Surat edaran Jenderal Pajak Nomor SE-15/PJ/2014 menyatakan bahwa dalam mencapai visi untuk menghimpun penerimaan Negara secara optimal harus dikaitkan dengan meningkatkan efektifitas pemeriksaan pajak yang merupakan sasaran strategis yang harus dicapai. Hal inilah yang diharapkan dari pemeriksaan pajak sebagai alat kendali untuk mengamankan penerimaan Negara. Dimana pemeriksa pajak harus memenuhi syarat dan melaksanakan kewajibannya yang berarti pemeriksa pajak telah menggunakan keterampilannya dengan cermat dan sesakma serta taat terhadap peraturan perundang-undangan perpajakan, dan pemeriksa pajak telah menyampaikan Surat Pemberitahuan Pemeriksaan Lapangan dan Kantor, memperlihatkan tanda pengenal dan Surat Perintah Pemeriksaan (SP2) maka, tingkat kinerja pemeriksa pajak sangat dibutuhkan untuk mencegah penyimpangan atas pelaporan pajak yang dilakukan Wajib Pajak dalam rangka meningkatkan penerimaan pajak.

Penelitian ini bertujuan untuk mengukur efektivitas pelaksanaan pemeriksaan pajak studi pada KPP Pratama Lubuk Pakam. Tingkat efektivitas pelaksanaan pemeriksaan pajak dapat diukur berdasarkan penyelesaian Surat Perintah Pemeriksaan (SP2) di setiap tahunnya serta berdasarkan realisasi penerimaan pemeriksaan pajak di KPP Pratam Lubuk Pakam.

Berdasarkan keterangan di atas maka dapat dirumuskan masalah penelitian sebagai berikut: " Bagaimana pengaruh pemeriksaan pajak terhadap kepatuhan wajib pajak badan pada Kantor Pelayanan Pajak Medan Petisah.

\section{DASAR TEORI}

\section{Pajak Sebagai Penerimaan Negara}

Pemungutan pajak merupakan perwujudan dari pengabdian kewajiban dan peran serta wajib pajak yang secara langsung dan bersama-sama melaksanakan kewajiban perpajakan yang diperlukan untuk pembiayaan negara dan pembangunan nasional. Penerimaan negara berupa minyak dan gas bumi, tetapi lebih berupaya untuk menjadikan pajak sebagai primadona penerimaan negara. Waluyo dan Wirawan (2003:5), dari sudut pandang ekonomi, pajak merupakan penerimaan negara yang digunakan untuk mengarahkan kehidupan masyarakat menuju kesejahteraan pajak sebagai motor penggerak kehidupan ekonomi masyarakat.

\section{Efektivitas}

Pengertian efektivitas adalah hubungan antara tujuan yang hendak dicapai dengan hasil yang telah dilakukan. Suatu pekerjaan dapat dikatakan efektif jika pekerjaan tersebut dapat mencapai target atau bahkan melebihi target yang ditetapkan. (Mardiasmo, 2002:152).

Rumus yang digunakan untuk melakukan pengukuran efektivitas pelaksanaan pemeriksaan pajak adalah sebagai berikut:

Efektivitas $=\frac{\text { Realisasi Penerimaan Pajak }}{\text { Target Penerimaan Pajak }} \times 100 \%$

Setelah dilakukan perhitungan efektivitas pelaksanaan pemeriksaan pajak, hasil perhitungan tersebut diklasifikasikan ke dalam tabel klasifikasi Kementrian Perdagangan dalam Negeri. No.690.900.327 tahun 1996, sebagai berikut:

Tabel 1. Klasifikasi Kriteria Efektivitas

\begin{tabular}{|l|l|l|}
\hline No & \multicolumn{1}{|c|}{ Persentase Efektivitas } & Kriteria \\
\hline 1 &.$>100 \%$ & Sangat Efektif \\
\hline 2 & $90 \%-100 \%$ & Efektif \\
\hline
\end{tabular}




\begin{tabular}{|l|l|l|}
\hline 3 & $80 \%-90 \%$ & Cukup Efektif \\
\hline 4 & $60 \%-80 \%$ & Kurang Efektif \\
\hline 5 & $<60 \%$ & Tidak Efektif \\
\hline
\end{tabular}

Sumbe

r: Kementrian Perdagangan dalam Negeri, 1996

\section{Pemeriksaan Pajak}

Pengertian pemeriksaan pajak adalah serangkaian kegiatan untuk mengumpulkan dan mengevaluasi data, dokumen, serta bukti- bukti tentang kegiatan usaha atau suatu entitas usaha Wajib Pajak yang dilakukan oleh pemeriksa pajak untuk menentukan dan melaporkan kesesuaian informasi tersebut dengan standar yang telah ditentukan dan menyampaikan hasil pemeriksaannya kepada pihak yang berkepentingan (Arens dan Loebbecke(2003).

\section{Petugas Pelaksanaan Pemeriksaan Pajak}

Ciri utama seorang pemeriksa pajak adalah ia harus memiliki Kartu Tanda Pengenal Pemeriksa Pajak. Pada kartu tersebut diuraikan bahwa pemegang kartu adalah pemeriksa pajak di wilayah tertentu. Ciri lainnya yaitu bahwa dalam pelaksanaan tugas-tugas pemeriksaannya ia dibekali surat tugas untuk melakukan pemeriksaan pajak dari atasannya yang berwenang yang disebut sebagai Surat Perintah Pajak (SP3) terhadap wajib pajak yang ditunjukkan. Sehingga, orang yang tidak dilengkapi dengan Kartu Tanda Pengenal Pemeriksa Pajak dan Surat Perintah Pemeriksaan Pajak (SP3) yang sah tidak berwenang melakukan pemeriksaan. Wajib pajak berhak menanyakan identitas orang tersebut dan melakukan konfirmasi keatasan orang tersebut.

\section{Penerimaan Pajak}

Penerimaan berasal dari kata tertulis yang berarti mendapat (memperoleh sesuatu), sedanngkan penerimaan pajak merupakan jumlah kontribusi masyarakat (yang dipungut Undang-Undang) yang diterima oleh negara dalam suatu masa yang akan digunakan untuk keperluan negara bagi sebesarbesarnya kemakmuran rakyat. Menurut Hutagaol dan Sitanggang (2014) "penerimaan pajak adalah sumber penerimaan yang dapat dikembangkan secara optimal sesuai kebutuhan pemerintah serta kondisi masyarakat".

\section{Faktor-faktor yang Mempengaruhi Pelaksanaan Pemeriksaan Pajak}

Menurut John Hutagaol yang dikutip Siti Kurnia Rahayu (2010:260), faktor-faktor yang mempengaruhi pelaksanaan pemeriksaan pajak, antara lain adalah:

a. Teknologi Informasi

Kemajuan teknologi informasi telah luas dimanfaatkan oleh WP. Seiring dengan pengembangan tersebut maka pemeriksa harus memanfaatkan perangkat teknologi informasi dengan Computer Assited Audit Tecnoloque (CAAT).

b. Jumlah Sumber Daya Manusia

Jumlah sumber daya manusia harus sebanding dengan beban kerja pemeriksaan. Untuk mengatasi jumlah pemeriksaan yang terbatas adalah dengan meningkatkan kualitas pemeriksaan dan melengkapinya dengan teknologi informasi didalam pelaksanaan pemerikssaan.

c. Kualitas Sumber Daya

Kualitas pemeriksaan sangat dipengaruhi oleh pengalaman, latar belakang, dan Pendidikan. Solusi agar kesenjangan kualitas pemeriksaan teratasi adalah dengan melalui Pendidikan dan pelatihan secara berkesinambungan dan sistem mutase yang terencana serta penerapan reward and punishment.

d. Sarana dan Prasarana Pemeriksaan

Sarana dan prasarana pemeriksaan seperti komputer sangat diperlukan, Audit Command Languange $(A C I)$, contohnya sangat membantu pemeriksa didalam mengelola data untuk tujuan Analisa penghitungan pajak. 


\section{Kerangka Berpikir}

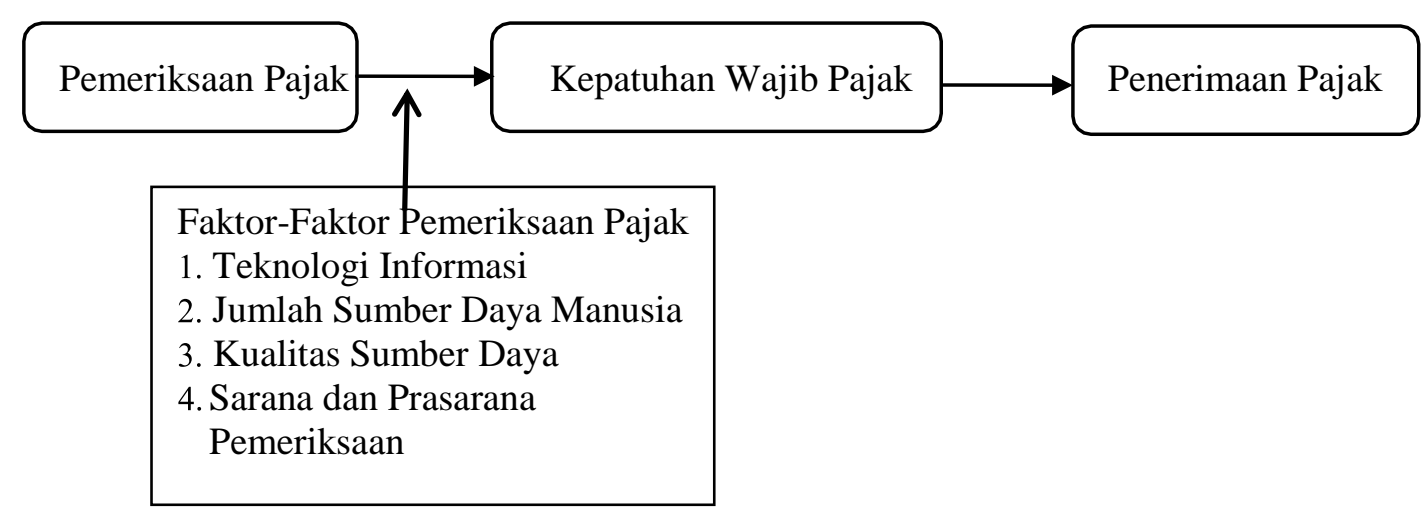

Gambar 1. Kerangka Berfikir

Sumber penerimaan Negara Indonesia berasal dari penerimaan pajak. Pajak merupakan salah satu sektor penerimaan negara yang paling besar dan memiliki fungsi yang sangat berpengaruh dalam suatu negara. Pajak dapat menjadi ukuran suatu negara dalam hal kemampuan untuk membiayai keperluan negara untuk meningkatkan kesejahteraan masyarakat. Kebutuhan dana untuk pembangunan setiap tahun semakin meningkat, sehingga Direktur Jenderal Pajak berusaha untuk meningkatkan penerimaan negara yang berasal dari sektor pajak. Setiap negara memiliki kewajiban penting untuk mencukupi kebutuhan masyarakat dengan melakukan pembangunan yang dimana dana untuk melaksanakan pembangunan tersebut cukup besar.

Pemeriksaan pajak dilaksanakan oleh petugas dari instansi pajak dalam rangka self assessment system yang adalah wujud nyata dari penegakan hukum dalam bidang pajak. Self Assesment System yang dapat membuka celah bagi wajib pajak untuk melaporkan jumlah pajak terutangnya tidak sesuai kenyataan. Oleh karena itu Direktorat Jenderal Pajak berkewajiban melakukan pengawasan dan pembinaan terhadap kepatuhan wajib pajak salah satunya melalui pemeriksaan pajak. Dalam mendukung pemeriksaan pajak, ada beberapa faktor yang mempengaruhinya, antara lain teknologi informasi, jumlah sumber daya manusia, kualitas sumber daya, sarana dan prasarana pemeriksaan. Jika hal tesebut dapat dilaksanakan dengan sebaibaiknya dan faktor-faktor pelaksanaan pemeriksaan maka upaya dalam meningkatkan penerimaan pajak tentunya akan tercapai.

\section{METODE PENELITIAN}

\section{Populasi dan Sampel}

Populasi dalam penelitian ini adalah seluruh Wajib Pajak Badan yang terdaftar pada Kantor Pelayanan Pajak Medan Petisah di Lingkungan Wilayah DJP Sumut I pada periode 20162018. Teknik penentuan sampel yang digunakan dalam penelitian ini adalah purposive sampling dengan pemilihan sampel berdasarkan pertimbangan (judgement sampling) yaitu memilih dengan menggunakan pertimbangan tertentu, yaitu hanya Wajib Pajak Badan yang pernah diperiksa oleh petugas pajak. Sedangkan sampel data yang dipergunakan dalam penelitian ini diperoleh dari seksi pemeriksaan di Kantor Pelayanan Pajak Pratama Medan Petisah.

\section{Operasionalisasi Variabel}

Operasional variabel merupakan penjelasan suatu variabel-variabel ke dalam indikator yang lebih terperinci, sehingga variabel tersebut dapat diketahui ukurannya. Dalam penelitian ini, variabel yang digunakan adalah:

a. Variabel Independen (X)

Variabel Independen adalah variabel yang nilainnya tidak terpengaruh oleh nilai variabel lainnya. Variabel Independen dalam penelitian ini adalah pemeriksaan pajak. Pemeriksaan Pajak adalah pemeriksaan yang dilakukan oleh petugas Kantor Pelayanan 
Pajak Pratama Medan Petisah. Pemeriksaan Pajak diartikan sebagai serangkaian kegiatan untuk mencari, mengumpulkan, memgolah data, informasi, dan atau keterangan lainnya yang berguna untuk menguji kepatuhan wajib pajak didalam pemenuhan kewajibannya di bidang perpajakan dan tujuan lainnya. Realisasi pemeriksaan pajak diukur dalam satuan per lembar Surat Perintah Pemeriksaan (SKP).

b. Variabel Dependen (Y)

Variabel dependen adalah variabel yang nilainnya dipengaruhi oleh nilai variabel lain. Variabel dari penelitian ini adalah kepatuhan wajib pajak badan. Kepatuhan wajib pajak badan adalah suatu tindakan ketaatan Wajib Pajak Badan dalam pemenuhan kewajiban perpajakannya. Kepatuhan Wajib Pajak Badan diukur dari jumlah pelaporan SPT yang dilaporkan Wajib Pajak Badan yang dibagi dengan jumlah Wajib Pajak Badan terdaftar dan dikalikan $100 \%$. Hasil dari pembagian dan perkalian tersebut akan menghasilkan datapersentase kepatuhan wajib pajak badan. Dalam hal ini, pengukuran jumlah pelaporan Surat Pemberitahuan (SPT) Wajib Pajak Badan diambil dari tahun 2016-2018. Indikator yang digunakan untuk mengukur kepatuhan wajib pajak antara lain:

1) Tepat waktu menyampaikan SPT dalam 2 tahun terakhir.

2) Tepat waktu membayar pajak

3) Tidak memiliki tunggakan pajak

4) Menyelenggarakan pembukuan,pencatatan sesuai dengan ketentuan perpajakan

5) Tidak pernah dijatuhi hukuman pidana di bidang perpajakan dalam 5 tahun terakhir.'

Pengukuran variabel kepatuhan wajib pajak badan menggunakan variabel dummy, dengan Kriteria sebagai berikut:

1. Jika kelima indikator di atas tidak terpenuhi maka wajib pajak tersebut dikategorikan sebagai wajib pajak tidak patuh dan diberi skor $=0$.

2. Jika kelima indikator di atas terpenuhi maka wajib pajak tersebut dikategorikan sebagai wajib pajak patuh dan diberi skor $=1$.

\section{Teknik Analisis Data}

\section{a. Analisis Statistik Deskriptif}

Analisis data yang digunakan dalam penelitian ini adalah statistic deskriptif. Analisis statistik deskriptif digunakan untuk mengetahui karakteristik sampel yang digunakan dan menggambarkan variabel-variabel dalam penelitian. Analisis statistik deskriptif meliputi jumlah, sampel, nilai minimum, nilai maksimum, nilai rata-rata dan standar deviasi.

\section{b. Analisis Regresi Logistik}

Pengujian hipotesis untuk mengetahui adanya pengaruh pemeriksaan pajak terhadap kepatuhan wajib pajak dilakukan dengan menggunakan analisis regresi logistik. Penggunaan analisis regresi logistik dikearenakan variabel dependen dalam penelitian ini yaitu kepatuhan wajib pajak badan merupakan data yang berbentuk dummy. Kepatuhan wajib pajak dinyatakan dengan nilai 0 untuk menunjukan wajib pajak tidak patuh dan nilai 1 untuk menunjukan wajib pajak patuh. Pengujian hipotesis dalam penelitian ini dilakukan dengan bantuan program statistik SPSS 22. Dalam penelitian ini peneliti menggunakan model regresi logistik, Amalia dan Gani (2015), model regresi yang digunakan untuk menguji hipotesis penelitian adalah sebagai berikut:

Keterangan:

$$
\ln =\frac{p}{1-p}=\beta 0+\beta 1 X+\varepsilon
$$

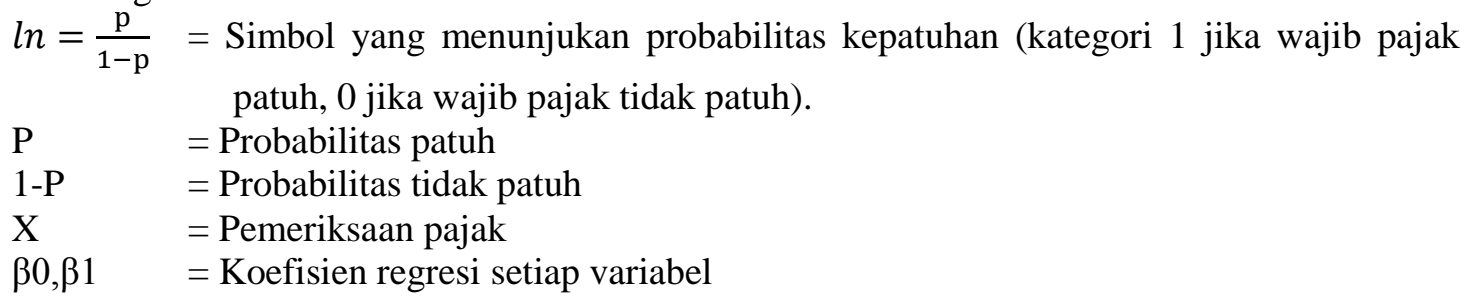


$\varepsilon$

$$
\text { = Kesalahan residual }
$$

\section{HASIL PENELITIAN DAN PEMBAHASAN}

Pembentukan KPP Pratama merupakan bagian program reformasi birokrasi perpajakan yang sifatnya komprehensif dan telah berjalan sejak tahun 2002 ditandai dengan terbentuknya kantor Wilayah Kanwil (Kanwil) dengan Kantor Pelayanan Pajak Wajib Pajak Besar. Terbentuknya KPP Pratama ini secara otomatis Kantor Pelayana Pajak Bumi dan Bangunan (KPPBB) dan kantor Pemeriksaan dan Penyidikan (Karipka) tidak ada lagi. Langkah ini diambil sebagai bagian dan usaha meningkatkan pelayanan kepada Wajib Pajak untuk memberikan pelayanan yang lebih baik dan personal dalam pelaksanaan good goverment. Kantor Pelayanan Pajak Pratama Lubuk Pakam didirikan pada tahun 2008 berdasarkan Keputusan Menteri Keuangan. Wilayah Kerja Kantor Pelayana Pajak Pratama Lubuk Pakam adalah Kabupaten Deli Serdang yang terdiri dari 22 kecamatan. Sebelumnya wilayah kerja Kantor Pelayanan Pajak Pratama Tebing Tinggi dan Kantor Pelayanan Pajak Pratama Binjai. Hal ini dilakukan untukmeningkatkan mutu pelayanan kepada wajib pajak. Dengan berdirinya KPP Pratama Lubuk Pakam diharapkan dapat meningkatkan efisiensi dan efektivitas pelayanan bagi wajib pajak yang berdomisili atau berlokasi di Kabupaten Deli Serdang.

\section{Deskripsi Data Penelitian}

Pemeriksaan pajak dilakukan berdasarkan surat perintah dari Direktorat Jenderal Pajak. Data yang digunakan untuk dianalisis adalah data penyelesaian Surat Perintah Pemeriksaan (SP2) dan data target dan realisasi penerimaan pajak atas hasil pemeriksaan pajak tahun 2016-2018 di KPP Pratama Lubuk Pakam.

Tabel 2. Data Penyelesaian Surat Perintah Pemeriksaan (SP2) di KPP Pratama Lubuk Pakam Tahun 2016-2018

\begin{tabular}{|l|l|l|l|}
\hline Tahun & $\begin{array}{l}\text { Target } \\
\text { Pemeriksaan }\end{array}$ & $\begin{array}{l}\text { Realisasi } \\
\text { Pemeriksaan }\end{array}$ & Belum Terealisasi \\
\hline 2016 & 1546 & 1314 & 232 \\
\hline 2017 & 2587 & 2276 & 271 \\
\hline 2018 & 1687 & 1547 & 138 \\
\hline
\end{tabular}

Sumber : KPP Pratama Lubuk Pakam

Tabel 3. Data Target dan Realisasi Penerimaan Pajak Atas Hasil Pemeriksaan Pajak di KPP Pratama Lubuk Pakam Tahun 2016-2018

\begin{tabular}{|l|l|l|}
\hline Tahun & Target Penerimaan & Realisasi Penerimaan \\
\hline 2016 & 83.303 .243 .000 & 69.020 .209 .945 \\
\hline 2017 & 95.355 .980 .000 & 73.931 .383 .926 \\
\hline 2018 & 81.862 .117 .917 & 72.928 .091 .618 \\
\hline
\end{tabular}

Sumber : KPP Pratama Lubuk Pakam

Dari tabel 2 dapat dilihat adanya kenaikan Surat Perintah Pemeriksaan (SP2) yang diterbitkan oleh KPP Pratama Lubuk Pakam di tahun 2017, namun ada penurunan di tahun 2018. KPP Pratama Lubuk Pakam belum bisa sepenuhnya menyelesaikan Surat Perintah Pemeriksaan (SP2) tersebut sehingga menimbulkan Surat Perintah Pemeriksaan (SP2) yang belum terlaksana untuk tahun berikutnya.

Dari tabel 3 seperti yang penulis jabarkan sebelumnya bahwa ada sesuatu hal yang terjadi di KPP Pratama Lubuk Pakam. Data yang didapat hanya tahun 2016-2018 saja. Pihak KPP Pratama Lubuk Pakam setiap tahunnya belum dapat mencapai target penerimaan yang telah ditentukan dari hasil pemeriksaan.

Perhitungan Pemeriksaan Pajak berdasarkan Data Penyelesaian Surat Perintah Pemeriksaan (SP2) 
Perhitungan efektivitas dari tahun 2016-2018 adalah sebagai berikut :

a. Tahun 2016

$$
\text { Efektivitas }=\frac{1314}{1546} \times 100 \%=84,99 \%
$$

b. Tahun 2017

$$
\text { Efektivitas }=\frac{2276}{2587+232} \times 100 \%=80,73 \%
$$

c. Tahun 2018

$$
\text { Efektivitas }=\frac{1547}{1685+271} \times 100 \%=79,08 \%
$$

Dari hasil penghitungan diatas dapat diketahui bahwa tingkat efektivitas yang dicapai berdasarkan penerbitan dan realisasi atas Surat Perintah Pemeriksaan (SP2) sebagai berikut :

a) Pada tahun 2016 yang dicapai adalah sebesar 84,99\% maka tingkat efektivitas yang di capai termasuk dalam kriteria cukupefektif.

b) Pada tahun 2005 yang dicapai adalah sebesar $100 \%$ maka tingkat efektivitas yang di capai termasuk dalam kriteria cukup efektif.

c) Pada tahun 2006 yang dicapai adalah sebesar $100 \%$ maka tingkat efektivitas yang di capai termasuk dalam kriteria kurangefektif.

Dari hasil penghitungan diatas dari tahun 2016-2018 mempunyai tingkat efektivitas dengan kriteria yang sama yaitu sebesar cukup efektif, karena KPP Pratama Lubuk Pakam bisa menyelesaikan Surat Perintah Pelaksanaan Pemeriksaan (SP3) dalam jangka waktu yang telah ditentukan, akan tetapi ada penumpukan Surat Perintah Pemeriksaan (SP2) tahun sebelumnya yang harus diakumulasikan pada tahun berikutnya. Selain itu Wajib Pajak kooperatif dalam melaksanakan pemeriksaan pajak sehingga tidak ada kesulitan yang terlalu mengkhawatirkan pemeriksa. Itu berarti kinerja dari KPP Pratama Lubuk Pakam sudah baik karena bisa memenuhi target yang telah ditentukan, dan sebaiknya KPP Pratama Lubuk Pakam bisa mempertahankan hal tersebut.

Wajib Pajak kooperatif yaitu WP memiliki pengetahuan yang cukup mengenai pajak dan tingkat kepatuhan yang relatif tinggi dengan selalu membayar pajak secara tepat waktu serta dalam pelaksanaan pemeriksaan pajak tidak mempersulit fiskus seperti tidak menolak untuk menunjukkan dokumen/buku/catatan yang diperlukan oleh pemerikasa, memberikan kesempatan pemeriksa untuk masuk kedalam ruangan yang dianggap penting oleh pemeriksa guna memperlancar pemeriksaan, dan memberikan keterangan secara jelas baik secara lisan maaupun tertulis kepada pemeriksa.

\section{Perhitungan Efektivitas Pelaksanaan Pemeriksaan Berdasarkan Target dan Realisasi Penerimaan Pajak atas Hasil Pemeriksaan}

Penghitungan efektivitas Pelaksanaan dari segi penerimaan atas hasil pemeriksaan adalah sebagai berikut :

a. Tahun 2016

$$
\text { Efektivitas }=\frac{69 \cdot 020 \cdot 209.945}{83 \cdot 303 \cdot 243.000} \times 100 \%=82,85 \%
$$

b. Tahun 2017

$$
\text { Efektivitas }=\frac{73.931 .393 .926}{95.355 .980 .000} \times 100 \%=77,53 \%
$$

c. Tahun 2018

$$
\text { Efektivitas }=\frac{72.928 .091 .618}{81.862 .117 .917} \times 100 \%=89,08 \%
$$

Dari hasil penghitungan dapat diketahui bahwa tingkat efektivitas yang dicapai berdasarkan target dan realisasi dari penerimaan atas hasil pemeriksaan sebagai berikut :

a) Pada tahun 2016 yang dicapai adalah sebesar 82,85\% maka tingkat efektivitas yang dicapai termasuk dalam kriteria cukup efektif.

b) Pada tahun 2017 yang dicapai adalah sebesar 77,53\% maka tingkat efektivitas yang dicapai termasuk dalam kriteria kurang efektif.

c) Pada tahun 2018 yang dicapai adalah sebesar $89,08 \%$ maka tingkat efektivitas yang dicapai termasuk dalam kriteria cukup efektif. 
Dimana terjadi kenaikan penerimaan pada tahun 2017 akan tetapi termasuk kriteria kurang efektif. Sedangkan pada tahun 2016 dan 2018 dikategorikan cukup efektif. Hal ini mungkin dikarenakan adanya kerjasama yang kooperatif antara petugas pemeriksa dengan Wajib Pajak baik yang mempunyai penghasilan besar, menengah, dan kecil. Mereka memiliki tingkat kesadaran dan kepatuhan yang relatif tinggi mengenai kewajiban perpajakannya.

Berarti pihak KPP Pratama Lubuk Pakam sudah cukup berhasil melakukan pendekatan dengan metode personal persuasif terhadap WP menengah dan kecil untuk kooperatif terhadap pelaksanaan pemeriksaan pajak. Yang dimaksud dengan metode personal persuasif adalah dengan melakukan pemantauan ke lapangan dengan melakukan kunjungan langsung ke tempat usaha atau ketempat tinggal WP untuk melihat kondisi yang sebenarnya terjadi.

Maka bisa dikatakan bahwa kedua indikator yang digunakan dalam pengukuran tersebut mempunyai keterkaitan yang melengkapi antara indikator satu dengan indikator yang lainnya. Indikator yang pertama merupakan penentu atas standar prestasi setiap pemeriksa pajak di KPP Pratama Lubuk Pakam yang telah ditetapkan oleh pusat Direktorat Jenderal Pajak. Sehingga, penghitungan efektivitas pelaksanaan pemeriksaan tidak dapat ditentukan hanya dengan menggunakan satu indikator saja tanpa melihat indikator lainnya.

\section{PEMBAHASAN}

Dari perhitungan efektivitas pelaksanaan pemeriksaan pajak berdasarkan data penyelesaian Surat Perintah Pemeriksaan (SP2) dan perhitungan efektivitas pelaksanaan pemeriksaan pajak berdasarkan target dan realisasi pemeriksaan pajak. Maka dapat disajikan di dalam tabel akan menjadi sebagai berikut :

Tabel 4. Data Target dan Realisasi Penerimaan Pajak Atas Hasil Pemeriksaan pajak dan Data Penyelesaian Surat Perintah Pemeriksaan (SP2) di KPP Pratama Lubuk Pakam Tahun 2016-2018

\begin{tabular}{|c|l|l|l|l|l|l|l|}
\hline Tahun & $\begin{array}{l}\text { Target } \\
\text { penerimaa } \\
\text { n }\end{array}$ & $\begin{array}{l}\text { Realiasasi } \\
\text { Penerimaan }\end{array}$ & $(\%)$ & $\begin{array}{l}\text { Jlh. } \\
\text { SP2 }\end{array}$ & $\begin{array}{l}\text { Realisasi } \\
\text { SP2 }\end{array}$ & $\begin{array}{l}\text { Belum } \\
\text { Terealisasi }\end{array}$ & $(\%)$ \\
\hline 2016 & 83.303 .243 .000 & 69.020 .209 .945 & $82,85 \%$ & 1546 & 1314 & 232 & $84,99 \%$ \\
\hline 2017 & 95.355 .980 .000 & 73.931 .383 .926 & $77,53 \%$ & 2587 & 2276 & 271 & $80,73 \%$ \\
\hline 2018 & 81.862 .117 .917 & 72.928 .091 .618 & $89,08 \%$ & 1685 & 1547 & 138 & $79,08 \%$ \\
\hline
\end{tabular}

Berdasarkan Tabel 4.3 dapat dilihat pada tahun 2016 tingkat efektivitas dari Surat Perintah Pemeriksaan (SP2) yang dihitung sebesar 84,99\% yang memiliki kategori cukup efektif begitu juga pada tahun 2017 tingkat efektivitas 80,73\% dikategorikan cukup efektif sedangkan pada tahun 2018 tingkat efektivitas Surat Perintah Pemeriksaan (SP2) hanya 79,08\% dikategorikan kurang efektif. Sedangkan dilihat dari Realisasi Penerimaan pajak dari Tahun 2016-2018 belum dapat mencapai target yang ditetapkan oleh KPP Pratama Lubuk Pakam. Realisasi Penerimaan Pajak tahun 2016 sebesar 69.020.209.945 sedangkan target penerimaan pajak yang ditetapkan 83.303.243.000 dikategorikan cukup efektif. Tahun 2017 realisasi penerimaan pajak sebesar 73.931.383.926 sedangkan target yang telah ditetapkan sebesar 95.355.980.000 dikategorikan kurang efektif sedangkan di tahun 2018 realisasi penerimaan pajak sebesar 72.928.091.618 dan target yang telah ditetapkan sebesar 81.862.117.917 dikategorikan cukup efektif.

Dari Uraian diatas dapat dinyatakan bahwa jumlah Surat Perintah Pemeriksaan (SP2) yang diterima mengalami kenaikan di tahun 2017 akan tetapi mengalami penurunan di tahun 2018 begitu juga jika dilihat dari tingkat efektivitas nya juga mengalami penurunan setiap tahunnya.

Jika dilihat dari target dan Realisasi Penerimaan setiap tahunnya Realisasi Penerimaan di KPP Pratama Lubuk Pakam mengalami Peningkatan tetapi belum bisa mencapai target yang telah ditetapkan sehingga dapat dikategorikan kurang efektif.

\section{Pelaksanaan Pemeriksaan Pajak pada KPP Pratama Lubuk Pakam}

Perencanaan Pemeriksaan dimulai dengan pembentukan tim pemeriksa pajak yang ditunjuk 
oleh Direktur Jenderal Pajak yang diberi tugas, wewenang, dan tanggung jawab untuk melaksanakan permeriksaan. Kemudian supervisor membuat rencana pemeriksaan, setelah rencana pemeriksaan disetujui oleh Kepala Unit Pelaksana Pemeriksaan (UP2) barulah diterbitkan Surat Perintah Pemeriksaan (SP2) merupakan kegiatan pemeriksaan pajak yang disampaikan atau diperlihatkan oleh tim pemeriksa pajak yang pajak dalam melaksanakan kewajiban perpajakannya dan untuk memenuhi hak wajib pajak yang diperiksa.

\section{Faktor-faktor yang Mempengaruhi Efektivitas Pelaksanaan Pemeriksaan}

Dengan melakukan wawancara yang lebih mendalam terhadap pihak-pihak yang terkait dan yang memegang peranan dalam pelaksanaan pemeriksaan, peneliti mencoba mendiskripsikan yang mempengaruhi efektivitas pelaksanaan pemeriksaan tersebut. Adapun faktor-faktor pendukung secara internal dalam pelaksanaan pemeriksaan yaitu dengan :

a. Informasi tentang Wajib Pajak yang jelas, karena ada jaringan yang menghubungkan KPP satu dengan KPP lainnya di seluruh Indonesia, setiap instansi sudah mengirimkan data tiap bulan secara online karena adanya Sistem Informasi Perpajakan (SIP) sehingga pekerjaan KPP Pratama Lubuk Pakam lebih cepat dan efisien.

b. Adanya dukungan dari pemeriksa pajak terhadap WP melalui pendekatan persuasif dimana pihak KPP Pratama Lubuk Pakam mengadakan komunikasi dengan beberapa asosiasi yang berdasarkan data yang ada baik intern dan ekstern, dan Wajib Pajak tersebut mau menanggapinya.

c. Laporan Surat Pemberitahuan (SPT) harus dilampiri dengan dokumen/ catatan/ data yang diperlukan oleh KPP Pratama Lubuk Pakam, maka dari itu petugas harus menelitinya dengan baik.

d. Sumber Daya Manusia (SDM) yang cukup dan baik dan mempunyai kemampuan untuk menangani pelaksanaan pemeriksaan

\section{Penyebab Tidak Tercapainya Target yang Telah Ditetapkan oleh KPP Pratama Lubuk Pakam}

Faktor penghambat dalam melaksanakan pemeriksaan, baik yang bersifat internal maupun eksternal. Adapun faktor-faktor penghambat yang mempengaruhi pelaksanaan pemeriksaan yang bersifat internal, yaitu :

a. Jumlah pemeriksa yang kurang, yaitu sebanyak 5 orang

b. Terlalu luasnya wilayah kerja KPP Pratama Lubuk Pakam. Wilayah kerja KPP Pratama Lubuk Pakam adalah Kabupaten Deli Serdang yang terdiri dari 22 kecamatan, sehingga tidak seimbang dengan jumlah pemeriksa yang melaksanakan pemeriksaan yang terlalu sedikit. Beban kerja pemeriksa menjadi semakin berat dan akan berpengaruh terhadap kualitas dan kuantitas kerja pemeriksa, sehingga hasil kerja menjadi tidak optimal.

Adapun faktor-faktor penghambat yang bersifat eksternal yang mempengaruhi pelaksanaan pemeriksaan, yaitu :

a. Tingkat pengetahuan Wajib Pajak yang kurang tentang pajak, terlebih masih banyaknya Wajib Pajak yang tidak bisa menghitung, memperhitungkan, melapor, dan meyetorkan sendiri kewajiban perpajakannya.

b. Dokumen yang diberikan oleh Wajib Pajak kepada petugas pemeriksa tidak seluruhnya diberikan sehingga pemeriksaan tidak berjalan lancar yang mengakibatkan penerimaan KPP Pratama Lubuk Pakam menjadi tidak optimal.

c. Jangka waktu dalam menyelesaikan pemeriksaan antara Wajib Pajak satu dengan yang lainnya tidak sama tergantung banyak sedikitnya dokumen yang akan diperiksa.

d. Pembukuan Wajib Pajak yang kurang lengkap dan kurang sesuai dengan standar perpajakan yang telah ditetapkan, karena Wajib Pajak biasanya membuat laporan keuangan hanya berdasarkan standar akuntansi tanpa memperhatikan standar perpajakannya.

e. Wajib Pajak yang tiba-tiba pindah alamat tanpa ada pemberitahuan dulu kepada KPP Pratama Lubuk Pakam, dimana pada saat petugas datang untuk memeriksa WP tersebut sudah tidak ada ditempat tinggalnya. 


\section{KESIMPULAN}

Berdasarkan hasil pembahasan yang telah dilakukan, maka kesimpulan adalah sebagai berikut: Tidak tercapainya target pemeriksaan pajak disebabkan karena adanya faktor-faktor penghambat yang mempengaruhi pelaksanaan pemeriksaan tersebut yang bersifat internal maupun eksternal, yaitu : jumlah pemeriksa yang kurang, terlalu luas wilayah KPP Pratama Lubuk Pakam yaitu Kabupaten Deli serdang yang terdiri dari 22 kecamatan. Serta tingkat pengetahuan Wajib Pajak yang kurang tentang pajak, terlebih masih banyaknya Wajib Pajak yang tidak bisa menghitung, memperhitungkan, melapor, dan meyetorkan sendiri kewajiban perpajakannya, jangka waktu pemeriksaan yang terlalu singkat, serta pembukuan wajib pajak yang kurang lengkap dan kurang sesuai dengan standart perpajakan.

\section{DAFTAR PUSTAKA}

Aryobimo P. T. 2012. Perpajakan, Edisi Revisi. Andi offset. Yogyakarta.

Amalia, Gani. 2015. Alat Analisis Data Penelitian Bidang Ekonomi Dan Sosial, Edisi Revisi. Andi offset. Yogyakarta.

Safitri,Arya Erwin.2010.Pengaruh Pemeriksaan Pajak Terhadap Penerimaan Pajak Penghasilan, Jurnal EMBA Vol.2.

Billy, Ricky dan Inggriani Elim. 2015. Analisis Efektivitas Pemeriksaan Pajak dalam Upaya Meningkatkan Penerimaan pajak, Jurnal EMBA Vol.3.

Burhanuddin. 2017. Pengaruh Pemeriksaan Pajak terhadap Tingkat Kepatuhan Wajib Pajak PPH Badan dalam Pemenuhan Kewajiban Perpajakannya. Skripsi Fakultas Ekonomi dan Bisnis Univ. Halu Oleo Kendari.

Erly,Suandy.2011. Perencanaan Pajak. Jakarta: SalembaEmpat.

Fakultas Ekonomi Universitas Katolik Santo Thomas Sumatera Utara Jurusan Akuntansi, 2019. Buku Petunjuk Teknik Penulisan Proposal Penelitian dan Penulisan Skripsi, Medan.

Ghozali, I, 2016. Aplikasi Analisis Multivariate Dengan Program SPSS. Semarang: BP. Undip.

Harahap H.N.H. 2013. Pengaruh Pelaksanaan Pemeriksaan Pajak Terhadap Tingkat Kepatuhan Wajib Pajak badan. Fakultas Ekonomi Universitas Pasundan. SkripsiUnpas. Bandung.

Priantara, Diaz. 2013. Perpajakan Indonesia. Jakarta: Penerbit Mitra Wacana Media.

Resmi,Siti.2013. Perpajakan Teori Kasus, Jakarta: SalembaEmpat.

Referensi dari Internet : www.pajak.go.id

Sitanggang,2014.Efektivitas Pelaksanaan Pemeriksaan Dalam Upaya Meningkatkan Penerimaan Negara di KPP Pratama Tulunggung.Skripsi (S1). UniversitasBrawijaya, Malang.

Siti Kurnia Rahayu. (2010). Perpajakan Indonesia: KonsepdanAspek Formal. Yogyakarta: GrahaIlmu.

Sarjono, Haryadi dan Winda Julianita. 2013.SPSS VS LISREL: Sebuah Pengantar, Aplikasi Untuk Riset, Jakarta: Salemba Empat. 
Siregar, Syofian. 2018. Statistika Parametrik untuk Penelitian Kuantitatif: Dilengkapi dengan Perhitungan Manual dan Aplikasi SPSS Versi 20. Jakarta: Bumi Aksara.

Undang-undang Nomor 16 Tahun 2000. Tentang Perubahan Ketiga atas undang-undang Nomor 6 Tahun 1983 Tentang Ketentuan Umum dan Tata Cara Perpajakan.

Undang- undangNomor 31 tahun 1968.Tata Cara Pemeriksaan Tentang Perpajakan Peraturan Pemerintah.

Waluyo. 2012. Akuntansi Pajak, Edisi 10, Salemba Empat, Jakarta.

Yun Tampubolon. 2015, Pengaruh pelaksanaan Pemeriksaan Pajak Dalam Meningkatkan Kepatuhan Wajib Pajak Badan Pada Kantor Pelayanan Pajak Pratama Medan Timur, Skripsi Fakultas Ekonomi dan Bisnis Islam Univ Islam Negeri Sumatera Utara. 